\title{
Literasi Keuangan, Inklusi Keuangan dan Minat Investasi Generasi Z di Jabodetabek
}

\section{Financial Literacy, Financial Inclusion, and Investment Interest Generation Z's in Jabodetabek}

\author{
Eka Dasra Viana* \\ Department of Management, Faculty of Economics and Management, Bogor University \\ e-mail: ekadasraviana@apps.ipb.ac.id \\ Firdha Febrianti \\ Department of Management, Faculty of Economics and Management, Bogor University \\ e-mail: firdhafebrianti@gmail.com \\ Farida Ratna Dewi \\ Department of Management, Faculty of Economics and Management, Bogor University \\ e-mail: faridadewi@gmail.com
}

\begin{abstract}
Indonesia's population is dominated by productive age, which is expected to contribute to boosting economic growth and improving people's welfare. The number of the young generation (Generation Z) is an advantage for Indonesia's demographics as well as opportunities and challenges in carrying out digital transformation, both in financial literacy and in the provision of products and services. However, the Financial Services Authority (OJK) in 2019 stated that the level of financial literacy and financial inclusion in Indonesia remains low. This condition might be due to the lack of understanding to the various financial products and services offered by formal financial services institutions. Significantly, Generation $Z$ has realize responsibility for their financial condition and is starting to honourably the importance of investing. Therefore in this study, the level of financial literacy and inclusion of Generation $Z$ in Jabodetabek was studied in order to analyze the effect on investment interest in the capital market. Descriptive analysis and Structural Equation Modeling (SEM) - PLS analysis were used for data generation. The results of this study reveal that the level of financial literacy and the average financial inclusion of Generation $Z$ in Jabodetabek are in the well literate category, financial literacy has no effect on investment interest, in contrary, the financial inclusion has an effect on investment interest.
\end{abstract}

Keywords: Financial inclusion, financial literacy, generation Z, investment interest.

\begin{abstract}
ABSTRAK
Penduduk Indonesia didominasi oleh usia produktif yang diharapkan dapat berkontribusi dalam mendorong pertumbuhan ekonomi maupun meningkatkan kesejahteraan masyarakat. Dominasi generasi muda merupakan bonus tersendiri bagi demografi Indonesia sekaligus peluang serta tantangan dalam melakukan transformasi digital baik dalam literasi keuangan maupun dalam penyediaan produk dan layanan sektor jasa keuangan. Namun, Otoritas Jasa Keuangan tahun 2019 menyatakan tingkat literasi keuangan dan inklusi keuangan masyarakat Indonesia masih rendah. Rendahnya literasi keuangan menunjukkan masyarakat belum memahami dengan baik berbagai produk dan layanan jasa keuangan yang ditawarkan oleh lembaga jasa keuangan formal. Generasi Z sejatinya memiliki tanggung jawab atas kondisi keuangannya dan mulai menyadari pentingnya berinvestasi. Tujuan penelitian ini adalah mengukur tingkat literasi dan inklusi keuangan pada generasi $Z$ di Jabodetabek, menganalisis pengaruh tingkat literasi keuangan dan inklusi keuangan generasi $\mathrm{Z}$ di Jabodetabek terhadap minat investasi di pasar modal. Analisis data yang digunakan adalah analisis deskriptif dan analisis Structural Equation Modeling (SEM) - PLS. Hasil dari penelitian ini mengungkapkan bahwa tingkat literasi keuangan dan rata-rata inklusi keuangan generasi $\mathrm{Z}$ di Jabodetabek termasuk kategori well literate, literasi keuangan tidak berpengaruh terhadap minat investasi, sementara inklusi keuangan berpengaruh terhadap minat investasi.
\end{abstract}

Kata kunci: Generasi Z, inklusi keuangan, literasi keuangan, minat investasi. 


\section{PENDAHULUAN}

Indonesia sedang berada pada era "bonus demografi" yang mana 68,7 persen atau sebanyak 183,36 juta jiwa dari jumlah penduduk merupakan usia produktif yaitu pada rentang usia 15-64 tahun (Badan Pusat Statistik, 2018). Kelompok usia tersebut dikenal sebagai generasi Z dan generasi Milenial (Howe \& Strauss, 2000). Beberapa tahun kedepan, seluruh generasi Z akan berada pada kelompok usia produktif sehingga diharapkan dapat berkontribusi dalam mendorong pertumbuhan ekonomi maupun meningkatkan kesejahteraan masyarakat. Dominasi generasi muda juga menjadi bonus tersendiri bagi demografi Indonesia sekaligus peluang serta tantangan dalam melakukan transformasi digital baik dalam literasi keuangan maupun dalam penyediaan produk dan layanan sektor jasa keuangan (OJK, 2020).

Filipiak dan Walle (2015) menyatakan bahwa terdapat hubungan yang signifikan antara usia dan literasi keuangan. Youth Finsight Survey (2018) menyebutkan bahwa milenial memiliki potensi besar dalam layanan keuangan digital dimana 95 persen memiliki smartphone dan 49 persen menggunakan internet banking. Literasi keuangan merupakan pemahaman dasar tentang konsep keuangan. Hasil penelitian Luno dan Dalia (2019) menunjukkan terdapat perbedaan prilaku antara menabung dan investasi pada generasi milenial, mereka mulai berkomitmen terhadap tanggung jawab keuangan dan menabung, tetapi masih memiliki tantangan yang signifikan dalam berinvestasi. Putri dan Rahyuda (2017) menyatakan bahwa peningkatan literasi keuangan akan berdampak pada perilaku investasi individu.

Organization for economic cooperation and development atau OECD (2016), menyatakan bahwa literasi keuangan tidak hanya pengetahuan dan pemahaman atas konsep dan risiko keuangan tapi juga kombinasi kesadaran, pengetahuan, keterampilan, sikap dan perilaku yang diperlukan untuk membuat suatu keputusan keuangan yang efektif untuk meningkatkan kesejahteraan keuangan (financial well-being) individu dan masyarakat dan berpartisipasi dalam bidang ekonomi. US Financial literacy and Education Commission dalam US National Strategy for Financial Literacy (2020) menggambarkan literasi keuangan sebagai keterampilan, pengetahuan dan alat yang menjadi bekal bagi individu untuk membuat keputusan dan tindakan keuangan untuk mencapai tujuan keuangan mereka (OJK, 2020). Otoritas Jasa Keuangan (OJK) Indonesia mendefinisikan literasi keuangan sebagai pengetahuan, keterampilan, dan keyakinan yang memengaruhi sikap dan perilaku untuk meningkatkan kualitas pengambilan keputusan dan pengelolaan keuangan dalam rangka mencapai kesejahteraan. Dengan demikian, konsep literasi keuangan bersifat multidimensi, tidak hanya mencerminkan pengetahuan tetapi juga keterampilan, sikap, dan prilaku yang sebenarnya (Morgan, 2020).

Inklusi keuangan sejatinya tidak dapat dipisahkan dengan literasi keuangan. Pernyataan ini didukung oleh Tustin (2010) yang menyatakan bahwa literasi keuangan melatih cara berpikir, kecerdasan, dan motivasi masyarakat dalam merencanakan dan menglola keuangannya. Meskipun literasi keuangan dan inklusi keuangan tidak dapat dipisahkan, tetapi pada kenyataannya tingkat inklusi keuangan yang tinggi tidak selamanya diikuti dengan tingkat literasi keuangan. Hal ini dapat dilihat dari hasil survei yang dilakukan OJK. Terdapat gap yang cukup besar antara tingkat literasi dan inklusi keuangan. Perbedaan tersebut dapat terlihat pada Gambar 1 berikut.

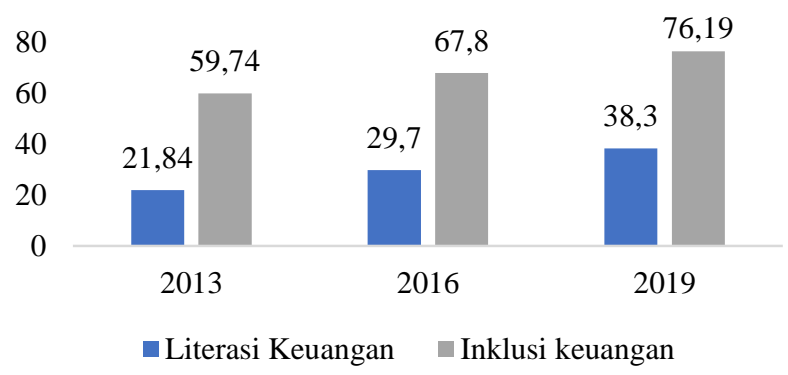

Gambar 1. Indeks Literasi dan Inklusi Keuangan di Indonesia (dalam persen) Sumber: Otoritas Jasa Keuangan (2013-2019) 
Gambar 1 menunjukkan bahwa terjadi peningkatan literasi keuangan nasional dalam satu dekade terakhir. Tahun 2019 terdapat 38,03 persen penduduk Indonesia yang memiliki tingkat literasi keuangan baik. Angka ini menunjukkan peningkatan dibandingkan hasil survei sebelumnya pada tahun 2013 dan 2016 yang nilainya hanya sebesar 21,84 persen dan 29,7 persen. Persentase tersebut mengindikasikan bahwa hanya 38 dari setiap 100 penduduk Indonesia yang termasuk ke dalam kelompok well literate. Hal ini berarti indeks literasi keuangan Indonesia masih tergolong rendah dan masih jauh dari indeks literasi keuangan negara-negara maju di dunia. Saat ini, Denmark, Norwegia, dan Swedia menempati tiga posisi tertinggi dengan indeks sebesar 71 persen (Klapper et al., 2015).

Rendahnya literasi keuangan menunjukkan masyarakat Indonesia belum memahami dengan baik berbagai produk dan layanan jasa keuangan yang ditawarkan oleh lembaga jasa keuangan formal. Menurut Shen (2018), literasi keuangan memberikan pengetahuan serta keterampilan keuangan yang digunakan untuk pembuatan keputusan keuangan. Rendahnya inklusi keuangan terhadap produk pasar modal, menggambarkan bahwa masyarakat Indonesia belum mengoptimalkan kekayaan yang dimilikinya untuk melakukan investasi. Rendahnya tingkat inklusi keuangan di bidang investasi dipengaruhi oleh literasi keuangan dan pendapatan (Dewi \& Purbawangsa, 2018). Akses terhadap pasar modal juga menjadi salah satu faktor yang memengaruhi minat investasi (Wibowo, 2018). Kesadaran masyarakat kelompok generasi Z terhadap investasi masih sangat rendah padahal generasi $Z$, yang termasuk juga ke dalam usia produktif, telah memiliki tanggung jawab atas kondisi keuangannya masing-masing, baik untuk saat ini maupun masa depan. TD Ameritrade melalukan penelitian terhadap generasi $Z$ di Amerika Serikat pada tahun 2012 yang hasilnya menyatakan bahwa baru 12 persen dari generasi $Z$ pernah memiliki produk investasi seperti saham, 72 persen belum pernah berinvestasi, dan bahkan 14 persen belum mengetahui tentang investasi. Fenomena dapat ini dikarenakan oleh salah satu karakteristik generasi Z yaitu lebih "risk-avoider" dan lebih memilih prinsip security dan stability terhadap apa yang dimilikinya saat ini. (Dwidienawati \& Gandasari, 2018)

Survei BPS dan Kemenpppa tahun 2018 menunjukkan bahwa 55 persen generasi milenial dan generasi $\mathrm{Z}$ Indonesia lebih banyak bertempat tinggal di wilayah perkotaan. salah satunya wilayah Jabodetabek. Sebagai pusat kegiatan nasional dan merupakan wilayah perkotaan terbesar di Indonesia menjadikan Kawasan Jabodetabek lebih maju terutama dalam aspek pendidikan dan perekonomian, yang mana daerah perkotaan memiliki indeks literasi dan inklusi keuangan yang lebih tinggi yaitu sebesar 41,41 persen dan 83,60 persen (OJK, 2019). Wilayah Jabodetabek adalah wilayah yang terdiri dari $14 \mathrm{kota} / \mathrm{kabupaten}$ yang tersebar kedalam tiga provinsi, yaitu provinsi DKI Jakarta, Jawa Barat, dan Banten. Wilayah Jabodetabek merupakan wilayah kota metropolitan yang menjadi pusat dari beberapa kegiatan, seperti ekonomi, perbankan, dan industri perdagangan. Wilayah Jabodetabek juga termasuk wilayah yang lebih maju dibandingkan dengan wilayah lain, termasuk dalam bidang pendidikan, perbankan, maupun perekonomian. Hal ini menjadi alasan bagi penulis memilih masayarakat generasi $\mathrm{Z}$ di Jabodetabek sebagai populasi sampel. Sehingga penelitian ini berjudul "Analisis Literasi dan Inklusi Keuangan terhadap Minat Investasi Generasi Z di Jabodetabek." Penelitian ini dilaksanakan pada generasi Z di Jabodetabek dengan tujuan (1) menganalisis tingkat literasi keuangan, (2) menganalisis tingkat inklusi keuangan, (3) menganalisis pengaruh literasi keuangan terhadap inklusi keuangan, dan (4) menganalisis pengaruh literasi dan inklusi keuangan terhadap minat investasi.

\section{METODE PENELITIAN}

\section{Kerangka Penelitian}

Yusitha (2017) menyatakan bahwa literasi keuangan dapat membantu seseorang terhindar dari permasalahan keuangan yang dapat terjadi terutama akibat kesalahan pengelolaan keuangan. Literasi keuangan adalah kemampuan dalam mengambil keputusan yang efektif mengenai penggunaan keuangan saat ini dan pengelolaan keuangan masa depan (Nyamute \& Maina, 2010). Hal ini selaras dengan yang disampaikan oleh OJK (2017) bahwa literasi keuangan sudah menjadi 
life skill bagi setiap individu agar mereka dapat merencanakan dan mengelola keuangan dengan baik untuk mencapai kesejahteraan

Metode pengambilan sampel yang dipakai dengan mempergunakan metode non probability sampling dengan teknik purposive sampling. Sugiono (2016) menyatakan "purposive sampling adalah teknik pengumpulan sampel dengan pertimbangan atau kriteria tertentu". Pada penelitian ini, kriteria yang digunakan adalah masyarakat yang termasuk dalam kelompok generasi Z (1525 tahun) dan bertempat tinggal di Jabodetabek, Penentuan ukuran sampel dalam penelitian ini menggunakan rumus Lemeshow. Rumus ini tepat untuk digunakan dalam penentuan penjumalahan dari populasi yang tidak diketahui penjumlahannya. Penelitian ini dilakukan dengan responden sebanyak 205 orang yang merupakan kelompok generasi $\mathrm{Z}$ berusia produktif (15-25 tahun) yang tinggal di daerah Jabodetabek. Pengambilan data dilakukan dengan menggunakan kuesioner yang diadaptasi dari OECD (2018) dan disebarluaskan secara online. Metode pengolahan dan analisis data yang digunakan adalah analisis deskriptif dan SEM-PLS. Alat yang digunakan untuk menganalisis data yaitu Microsoft Excel 2017 dan SmartPLS 3.

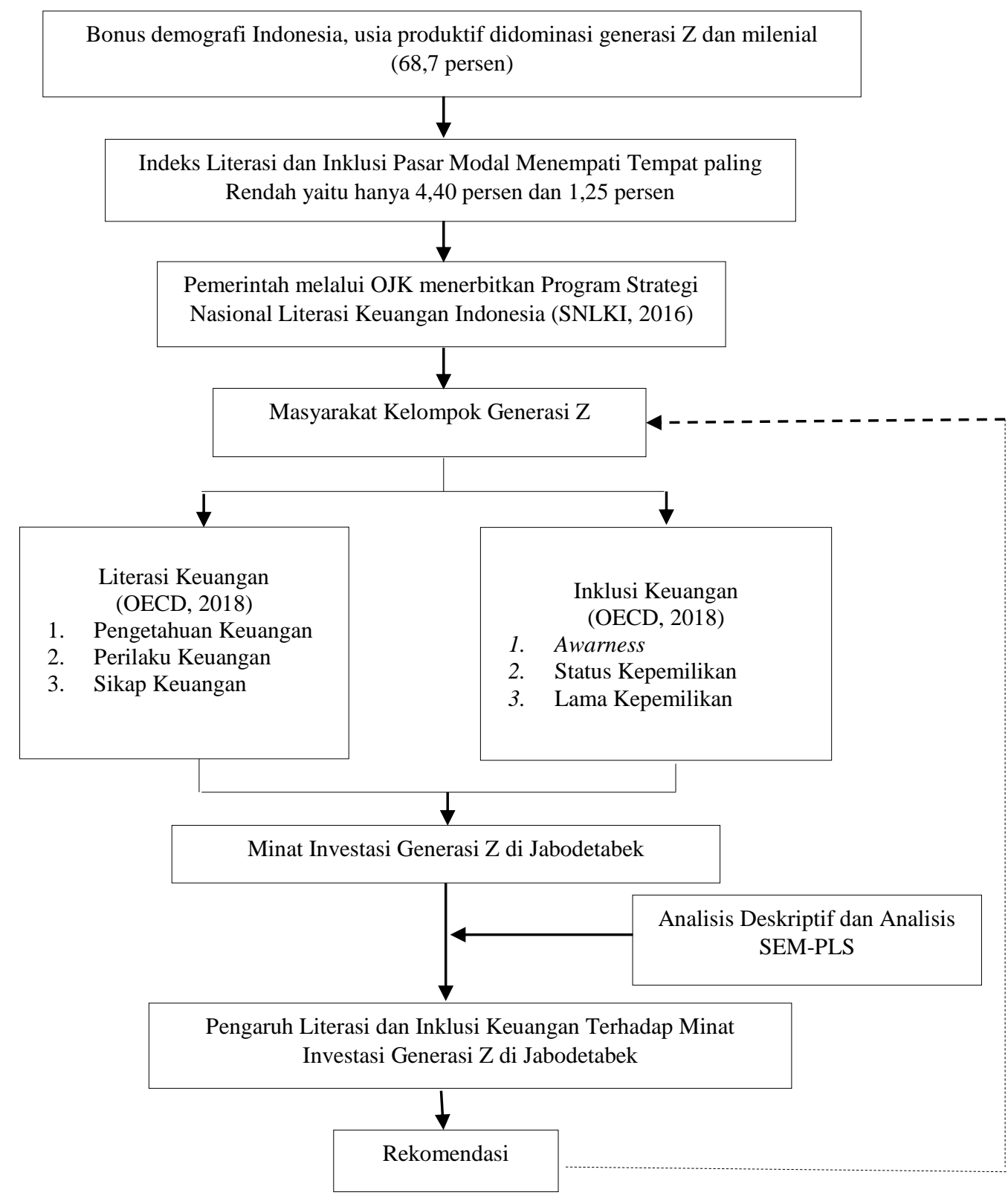

Gambar 2. Kerangka penelitian 


\section{Perumusan Hipotesis}

Perumusan hipotesis pada pengkajian ini yaitu:

a. $\quad$ Pengaruh Literasi Keuangan Terhadap Minat Investasi Generasi Z di Jabodetabek

Tingkat literasi keuangan untuk sektor pasar modal menempati posisi paling rendah dibandingkan dengan sektor keuangan lainnya, yaitu hanya sebesar 4,4 persen (OJK, 2017). Selain nilainya yang masih rendah, ternyata minat berinvestasi di pasar modal bagi generasi $\mathrm{Z}$ juga belum optimal. Berdasarkan penelitian, generasi $Z$ yang pernah dan/atau sedang memiliki produk pasar modal jumlahnya baru mencapai 12 persen (TD Ameritrade, 2012). Benjamin et al. (2013) membuktikan bahwa kemampuan pengetahuan keuangan yang rendah berhubungan dengan tingkat toleransi risiko keuangan yang lebih rendah. Ini berarti individu dengan tingkat literasi keuangan yang lebih rendah akan lebih cenderung menghindari risiko. Tingkat literasi keuangan tertentu diperlukan untuk memahami risiko yang terkait dengan produk investasi, sehingga pengetahuan ini penting bagi investor untuk mengambil keputusan keuangan, terutama keputusan yang penting seperti investasi jangka panjang

Penelitian yang dilakukan oleh Faidah (2019) menyatakan bahwa adanya dampak yang baik dan jelas, dengan literasi keuangan dan hal demografi minat penanaman modal. Hal tersebut, pengartiannya dengan tingkatan literasi meningkat, maka minat untuk berinvestasi akan ikut meningkat. Beralaskan penjelasan dengan hipotesa pengkajian yaitu:

$\mathrm{H}_{1}$ : Literasi keuangan tidak berpengaruh terhadap minat investasi

$\mathrm{H} 1_{1}$ : Literasi keuangan berpengaruh positif dan signifikan terhadap minat investasi.

b. Pengaruh Inklusi Keuangan Terhadap Minat Investasi Generasi Z di Jabodetabek

Penelitian yang dilakukan oleh Hasundungan (2019) menyatakan bahwa terdapat pengaruh yang positif dan siginifikan antara inklusi keuangan dengan perilaku investasi. Dengan adanya perbedaan antara tingkat inklusi keuangan secara keseluruhan, tingkat inklusi keuangan terhadap pasar modal, dan hasil penelitian sebelumnya, maka diperoleh pendugaan hipotesis yaitu:

H02: Inklusi keuangan tidak berpengaruh terhadap minat investasi

H12: Inklusi keuangan berpengaruh positif dan signifikan terhadap minat investasi.

\section{HASIL DAN PEMBAHASAN}

\section{Tingkat Literasi dan Inklusi Keuangan Generasi Z di Jabodetabek}

Penelitian ini menggunakan instrument kuesioner yang diadaptasi dari OECD (2018). Pada penelitian ini terdapat dua variabel independen dan satu variabel dependen. Variabel dependen yaitu literasi keuangan dan inklusi keuangan. Variabel literasi keuangan terdiri dari tiga sub variabel yaitu pengetahuan keuangan dengan tujuh indikator, perilaku keuangan dengan 8 indikator, dan sikap keuangan dengan tiga indikator. Variabel inklusi keuangan terdiri dari 21 pertanyaan yang mengukur awareness, status kepemilikan, dan lama kepemilikan produk-produk tabungan, produk pembayaran, produk asuransi, dan produk pinjaman/kredit. Sementara variabel minat investasi terdiri dari tiga pertanyaan yaitu tentang status kepemilikan produk-produk pasar modal, jenis produk apa yang dimiliki dan pertanyaan terbuka yang menilai alasan responden jika tidak berinvestasi.

Pada penelitian ini terdapat 205 responden yang termasuk ke dalam kelompok generasi Z usia produktif (15-25 tahun) yang tersebar di Jakarta, Bogor, Depok, Tangerang, Bekasi. Karakteristik responden penelitian ini terbagi ke dalam beberapa kategori, yaitu jenis kelamin, tempat tinggal, pendidikan terakhir, pekerjaan, dan pendapatan perbulan. Tingkat literasi keuangan dan inklusi keuangan generasi $\mathrm{Z}$ di Jabodetabek dilakukan dengan analisis deskriptif yang mengacu pada pengertian dari Otoritas Jasa Keuangan. Hasil analisis deskriptif untuk tingkat literasi dan inklusi keuangan generasi $\mathrm{Z}$ di Jabodetabek ditunjukkan dalam Tabel 1 dan Tabel 2. 
Tabel 1. Tingkat literasi keuangan responden

\begin{tabular}{lcccc}
\hline \multicolumn{1}{c}{ Sub Variabel } & \multicolumn{4}{c}{ Kategori Tingkat Literasi Keuangan } \\
\cline { 2 - 5 } & $\begin{array}{c}\text { No Literate } \\
(0-24 \%)\end{array}$ & $\begin{array}{c}\text { Less Literate } \\
(25-49 \%) \\
(\text { orang) }\end{array}$ & $\begin{array}{c}\text { Sufficient } \\
\text { Literate }(50-\end{array}$ & $\begin{array}{c}\text { Well Literate } \\
(75-100 \%) \\
\text { (orang) }\end{array}$ \\
\hline Pengetahuan Keuangan & 1 & 26 & $74 \%)$ (orang) & 45 \\
Perilaku Keuangan & 2 & 8 & 133 & 161 \\
Sikap Keuangan & 0 & 12 & 34 & 116 \\
Literasi Keuangan & 0 & 3 & 77 & 125 \\
& $0 \%$ & $1 \%$ & $38 \%$ & $61 \%$ \\
\hline
\end{tabular}

Sumber: Data primer, data diolah (2020)

Tabel 2. Tingkat inklusi keuangan responden

\begin{tabular}{lccc}
\hline \multicolumn{1}{c}{ Produk } & Nilai terendah $(\%)$ & Nilai tertinggi $(\%)$ & Rata-rata $(\%)$ \\
\hline Tabungan/Investasi & 50 & 100 & 60 \\
Produk Pembayaran & 50 & 100 & 90 \\
Asuransi & 50 & 100 & 68 \\
Pinjaman/Kredit & 83 & 50 & 53 \\
Inklusi Keuangan & 50 & 81 & 64 \\
\hline
\end{tabular}

Sumber: Data primer, data diolah (2020)

Dari tabel diatas, dapat diketahui bahwa tingkat literasi keuangan generasi $\mathrm{Z}$ di Jabodetabek yang termasuk ke dalam kelompok well literate sebesar 61 persen, angka ini lebih rendah dibandingkan penelitian sebelumnya yang dilakukan OJK (2019) kepada masyarakat Indonesia yaitu sebesar 67,8 persen. Rata-rata tingkat inklusi keuangan generasi $Z$ di Jabodetabek yaitu 64 persen lebih rendah daripada survei yang dilakukan OJK (2019) yaitu sebesar 76,19 persen.

\section{Minat Investasi Generasi Z di Jabodetabek}

Investasi merupakan kegiatan atau aktivitas menempatkan modal berupa uang maupun asset berharga dengan harapan investor akan memperoleh keuntungan setelah kurun waktu tertentu. Investasi dapat berbentuk properti, emas, dan investasi di pasar modal. Pada penelitian ini, hanya dibahas mengenai investasi di pasar modal.

Generasi $\mathrm{Z}$ adalah generasi cenderung untuk menghindari risiko (risk-averse) dan memiliki ekspetasi yang lebih rendah dibandingkan generasi-generasi sebelumnya. Generasi Z juga cenderung lebih menyukai keamanan dan kestabilan. Hal tersebut juga dapat dilihat dalam penelitian ini. Dari 205 orang responden, terdapat 23 orang atau 11 persen responden yang telah melakukan investasi. Jenis investasi yang dimiliki responden penelitian ini didominasi oleh saham, lalu diikuti dengan reksadana, obligasi, dan sukuk.

Setelah dilakukan wawancara dengan responden, terdapat beberapa alasan mengapa responden belum berinvestasi di pasar modal. Sebanyak 102 orang responden menyatakan bahwa responden belum bekerja dan belum memiliki penghasilan sendiri sehingga responden belum memutuskan untuk berinvestasi. Sedangkan sebanyak 35 responden menyatakan bahwa pendapatan yang dimiliki saat ini masih digunakan untuk memenuhi kebutuhan pokoknya sehingga belum memiliki modal untuk melakukan investasi di pasar modal. Hal ini juga sesuai dengan karakteristik responden yang sebagian besar berpendapatan $\leq \mathrm{Rp} 1.000 .000$ yakni sebear 38,54 persen dan juga responden yang berprofesi sebagai mahasiswa sebanyak 54,63 persen. Sisanya, sebanyak 45 orang responden beranggapan bahwa mereka belum tertarik untuk berinvestasi karena belum mengerti tentang sistem dan prosedur yang berlaku.

\section{Hasil Analisis SEM-PLS}

\section{Evaluasi Model Pengukuran (Outer Model)}

\section{a. Convergent Validity}

Untuk mengukur seberapa besar indikator-indikator yang ada dalam menerangkan variabel latennya, maka digunakan convergent validity. Artinya, "semakin besar convergent validity, maka 
semakin besar kemampuan indikator tersebut dalam menerangkan variabel latennya. Convergent validity terdiri dari reliability item (validitas indikator) dan average variance extracted (AVE)".

i. Reliability item

Pengujian terhadap "realiability item dapat dilihat dari nilai loading factor. Nilai loading factor ini merupakan besarnya korelasi antara setiap indikator terhadap setiap variabel latennya. Nilai loading factor diatas 0.6 dapat dikatakan ideal" (Hair et al. 2014), artinya indikator tersebut dapat dikatakan valid sebagai indikator yang mengukur variabel laten. Pada Gambar 3, dapat dilihat nilai standardized loading factor baik antar variabel laten maupun variabel laten ke masing-masing indikatornya.

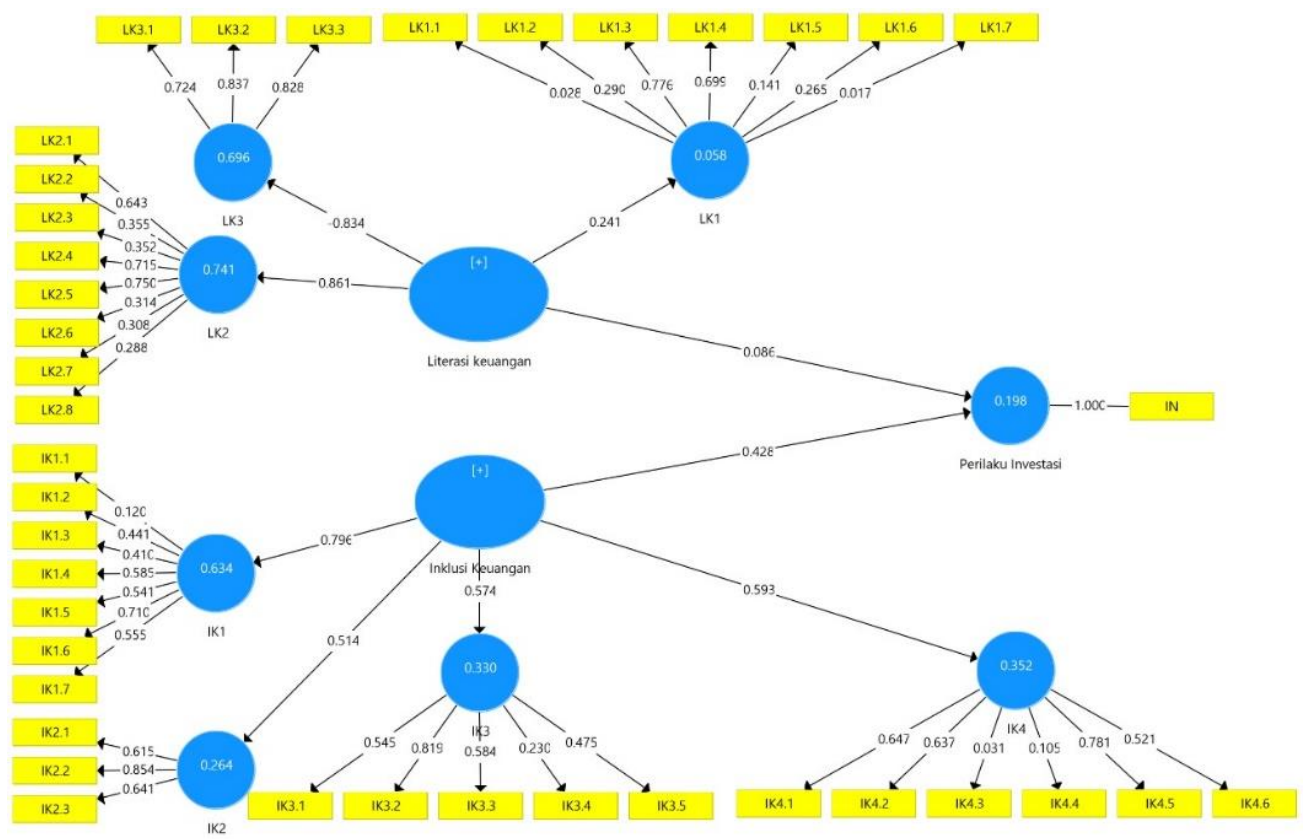

Gambar 3. Outer Model sebelum reduksi (dropping)

Sumber: Data diolah (2020)

Berdasarkan Gambar 3, terdapat beberapa indikator pada variabel laten dengan Standardized loading factor kurang dari 0,6 sehingga harus direduksi dari model (dropping). Indikator-indikator dari sub-variabel LK1 (pengetahuan keuangan) yang direduksi antara lain LK1.1, LK1.2, LK1.5, LK1.6, dan LK1.7. Sedangkan untuk indikatorindikator sub-variabel LK2 (perilaku keuangan), yaitu LK2.2, LK2.3, LK2.6, LK2.7, dan LK2.8. Sub-variabel IK1 (nilai inklusi produk tabungan dan investasi) terdiri dari 7 indikator, dengan 4 indikator yang harus direduksi yaitu IK1.1, IK1.2, IK1.3, dan IK1.5. Indikator dari sub-variabel IK2 (nilai inklusi produk pembayaran) yang direduksi adalah IK2.1 sedangkan sub-variabel IK3 (nilai inklusi produk asuransi) yang dilakukan reduksi adalah indikator IK3.1, IK3.4, dan IK3.5. Sementara indikator sub-variabel IK4 (nilai inklusi produk pnjaman/kredit) yang di reduksi adalah IK4.3, IK4.4, dan IK4.6. Berikut outer model yang dan nilai loading factor setelah dilakukan reduksi (dropping). 
Gambar 4 menunjukkan outer model setelah dilakukan reduksi terhadap indikatorindikator yang tidak valid. Pada Gambar 4, terlihat bahwa nilai standardized loading factor setiap indikator lebih besar dari 0.6 (Hair et al., 2014). Artinya, indikator-indikator pada outer model tersebut telah valid sebagai alat ukur untuk variabel latennya.

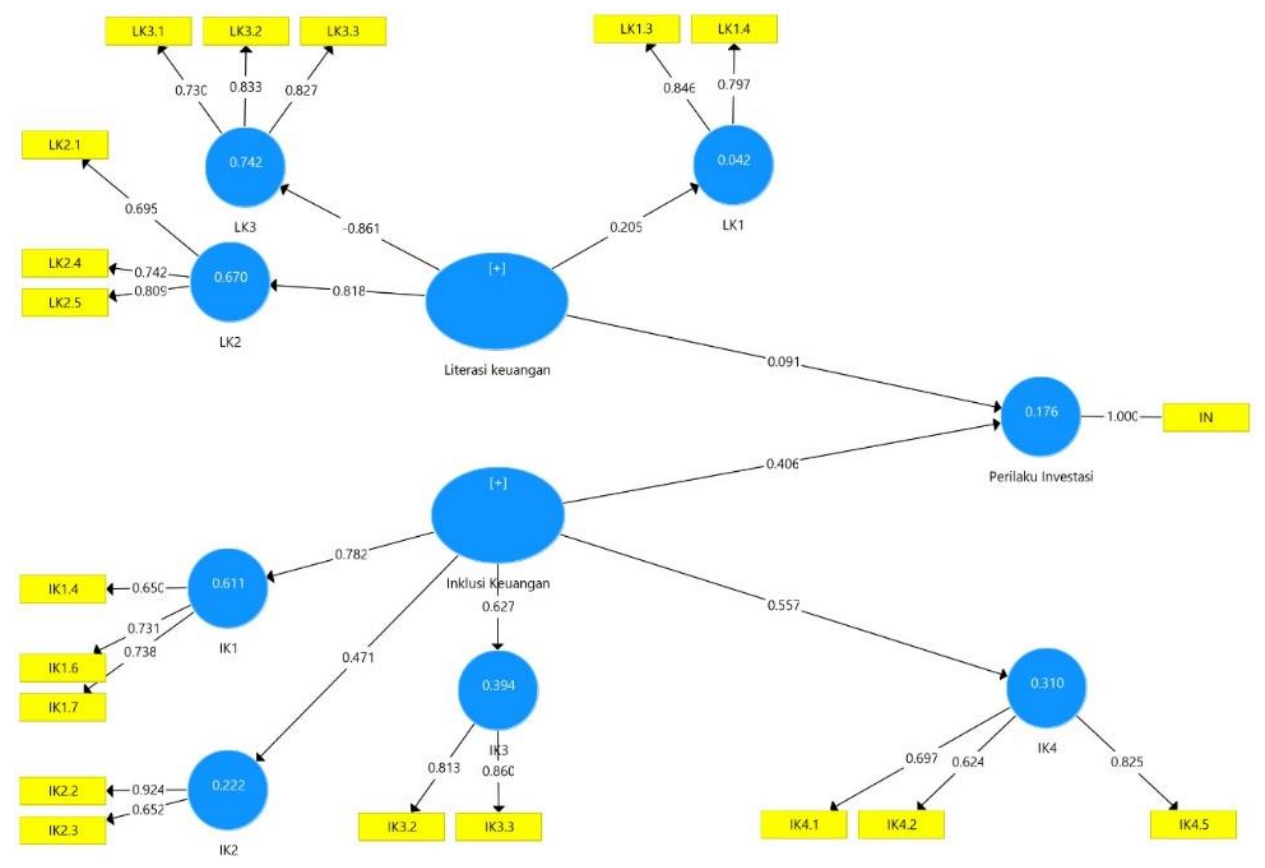

Gambar 4. Outer Model setelah direduksi (dropping)

Sumber: Data diolah (2020)

\section{ii. $\quad$ Average Variance Extracted (AVE)}

Average variance extracted (AVE) menggambarkan seberapa besar variance yang mampu dijelaskan oleh indikator-indikator setiap variabel dibandingkan dengan variance yang disebabkan oleh error pengukuran. Sebuah variabel laten dapat dikatakan memiliki convergent validity yang baik apabila memiliki nilai AVE lebih besar dari 0.5 (Hair et al., 2014). Nilai AVE dari variabel-variabel laten setelah dilakukan reduksi terhadap indikatorindikatornya terdapat pada Tabel 3.

Tabel 3. Nilai average varianve extracted

\begin{tabular}{ccc}
\hline Variabel laten & $\begin{array}{c}\text { Average variance extracted } \\
\text { (AVE) }\end{array}$ & Keterangan \\
\hline LK1 & 0.675 & Valid \\
LK2 & 0.563 & Valid \\
LK3 & 0.637 & Valid \\
IK1 & 0.500 & Valid \\
IK2 & 0.640 & Valid \\
IK3 & 0.700 & Valid \\
IK4 & 0.519 & Valid \\
Perilaku Investasi & 1.000 & Valid \\
\hline
\end{tabular}

Sumber: Data primer, data diolah (2020)

Berdasarkan pada Tabel 3 variabel sudah lebih besar dari 0.5. Artinya variabel laten sudah memiliki convergent validity yang baik dimana variabel laten dapat menjelaskan rata-rata lebih dari setengah variance dari indikator-indikatornya.

Jurnal Manajemen dan Organisasi

Vol. 12 (2)

Vol. 12 No. 3, Hal. 252-264

\section{b. Discriminant Validity}

Validitas diskriminan dari model pengukuran refleksif dapat dihitung berdasarkan nilai cross loading dari indikator terhadap masing-masing variabel laten. Ukuran cross loading dapat dilihat dengan cara membandingkan korelasi indikator dengan variabel laten dan variabel laten 
dari blok lain. Discriminant validity yang baik mampu menjelaskan variabel indikatornya lebih tinggi dibandingkan dengan menjelaskan varian dari indikator pada variabel laten yang lain. Pada Tabel 4 menunjukkan nilai discriminant validity untuk masing-masing indikator.

Berdasarkan Tabel 4 menunjukkan bahwa semua nilai loading factor untuk tiap indikator memiliki korelasi yang lebih tinggi dengan variabel latennya dibandingkan dengan variabel laten lainnya. Ini menunjukkan bahwa penempatan indikator pada setiap dimensi atau variabel latennya sudah tepat.

Tabel 4. Nilai Cross Loading

\begin{tabular}{lcccccccc}
\hline & LK1 & LK2 & LK3 & IK1 & IK2 & IK3 & IK4 & Minat Investasi \\
\hline LK1.3 & 0,846 & 0,054 & $-0,075$ & 0,158 & 0,168 & 0,030 & 0,117 & 0,146 \\
LK1.4 & 0,796 & 0,075 & $-0,031$ & 0,090 & 0,051 & $-0,009$ & 0,028 & 0,137 \\
LK2.1 & 0,017 & 0,695 & $-0,314$ & 0,003 & $-0,017$ & $-0,067$ & 0,028 & 0,069 \\
LK2.4 & 0,066 & 0,742 & $-0,319$ & $-0,030$ & 0,031 & 0,080 & 0,029 & 0,006 \\
LK2.5 & 0,087 & 0,809 & $-0,342$ & 0,076 & 0,003 & 0,002 & $-0,006$ & 0,087 \\
LK3.1 & $-0,035$ & $-0,251$ & 0,730 & $-0,054$ & $-0,036$ & $-0,033$ & $-0,010$ & $-0,015$ \\
LK3.2 & $-0,055$ & $-0,047$ & 0,833 & $-0,099$ & 0,072 & 0,100 & 0,071 & $-0,092$ \\
LK3.3 & $-0,065$ & $-0,282$ & 0,827 & $-0,032$ & 0,048 & 0,044 & $-0,091$ & $-0,075$ \\
IN & 0,172 & 0,073 & $-0,080$ & 0,556 & 0,203 & 0,116 & $-0,011$ & 1,000 \\
IK1.4 & 0,139 & 0,001 & $-0,017$ & 0,651 & 0,136 & 0,113 & 0,190 & 0,256 \\
IK1.6 & 0,164 & 0,114 & $-0,136$ & 0,731 & 0,101 & 0,070 & 0,084 & 0,567 \\
IK1.7 & 0,042 & $-0,046$ & $-0,026$ & 0,737 & 0,152 & 0,352 & 0,185 & 0,367 \\
IK2.2 & 0,118 & 0,025 & 0,005 & 0,196 & 0,924 & 0,137 & 0,129 & 0,149 \\
IK2.3 & 0,108 & $-0,029$ & 0,092 & 0,074 & 0,652 & 0,055 & $-0,064$ & 0,210 \\
IK3.2 & 0,035 & $-0,008$ & 0,029 & 0,178 & 0,165 & 0,813 & 0,096 & 0,115 \\
IK3.3 & $-0,008$ & 0,020 & 0,060 & 0,273 & 0,063 & 0,860 & 0,197 & 0,081 \\
IK4.1 & 0,067 & 0,023 & $-0,032$ & 0,016 & 0,005 & 0,098 & 0,697 & $-0,050$ \\
IK4.2 & 0,013 & 0,117 & $-0,095$ & 0,147 & 0,096 & 0,124 & 0,625 & $-0,046$ \\
IK4.5 & 0,107 & $-0,064$ & 0,077 & 0,253 & 0,057 & 0,154 & 0,824 & 0,044 \\
\hline
\end{tabular}

Sumber: Data pimer, data diolah (2020)

c. Composite Reliability

Uji Realibilitas mengunakan nilai Composite Reliability yang nilainya harus lebih dari 0.7 (Hair et al. 2014). Jika nilai Composite Reliability pada masing- masing variabel laten lebih besar dari 0.7 menunjukkan bahwa indikator-indikator memiliki kekonsistenan dalam mengukur variabel latennya masing-masing. Nilai Composite Reliability disajikan pada Tabel 5.

Tabel 5. Nilai Composite reliability pada variabel laten

\begin{tabular}{ccc}
\hline Variabel Laten & Nilai Composite Reliability & Keterangan \\
\hline LK1 & 0,806 & Reliabel \\
LK2 & 0,794 & Reliabel \\
LK3 & 0,840 & Reliabel \\
IK1 & 0,750 & Reliabel \\
IK2 & 0,775 & Reliabel \\
IK3 & 0,824 & Reliabel \\
IK4 & 0,761 & Reliabel \\
Minat Investasi & 1,000 & Reliabel \\
\hline
\end{tabular}

Sumber: Data primer, data diolah (2020)

Berdasarkan Tabel 5 diperoleh hasil bahwa seluruh nilai Composite Reliability pada semua variabel laten lebih dari 0.7 sehingga dapat dinyatakan bahwa seluruh variabel laten telah reliabel. Oleh karena itu dapat disimpulkan bahwa indikator-indikator memiliki kekonsistenan dalam mengukur variabel latennya masing-masing.

\section{Model Struktural (Inner Model)}

Model struktural adalah model yang menghubungkan variabel laten exogenous (X) dengan Jurnal Manajemen variabel laten endogenous $(\mathrm{Y})$ atau hubungan variabel endogenous $(\mathrm{Y})$ dengan variabel endogenous (Y) lainnya. Pengujian model struktural (inner model) dilakukan dengan melihat nilai 
$R$-Square $\left(R^{2}\right)$. Nilai $R$-Square $\left(R^{2}\right)$ ini digunakan untuk mengukur seberapa besar pengaruh variabel laten independen tertentu terhadap variabel laten dependen tertentu (Ghozali, 2014). Nilai R-Square (R2) pada penelitian ini dapat dilihat pada Tabel 6.

Tabel 6. Nilai $R$-Square

\begin{tabular}{cc}
\hline Variabel Laten & $R$-Square $\left(R^{2}\right)$ \\
\hline Minat Investasi & 0,177 \\
\hline
\end{tabular}

Sumber: Data primer, data diolah (2020)

Dari Tabel 6 dapat dilihat bahwa nilai R-Square pada variabel investasi sebesar 0,177. Ini artinya keragaman keragaman variabel inklusi keuangan dan literasi keuangan mampu menjelaskan variabel minat investasi sebesar 17,7 persen dan sisanya dijelaskan oleh variabel lain diluar model. Pengujian yang dilakukan selanjutnya adalah menguji hipotesis yang dapat dilihat dari hasil path analysis. Hasil perhitungan koefisien-koefisien path analysis untuk model struktural diperlihatkan dalam Tabel 7 berikut.

Tabel 7. Hasil pengaruh langsung pada model

\begin{tabular}{lccccc}
\hline \multicolumn{1}{c}{$\begin{array}{c}\text { Hubungan Variabel } \\
\text { Laten }\end{array}$} & $\begin{array}{c}\text { Original } \\
\text { Sample }\end{array}$ & $\begin{array}{c}\text { Standard } \\
\text { Deviation }\end{array}$ & T Statistics & P-Values & Hipotesis \\
\hline $\begin{array}{l}\text { Literasi Keuangan -> } \\
\text { Minat Investasi }\end{array}$ & 0,091 & 0,095 & 0,963 & 0,336 & Terima $_{0}$ \\
$\begin{array}{l}\text { Inklusi Keuangan -> } \\
\text { Minat Investasi }\end{array}$ & 0,406 & 0,104 & 3,903 & $0,000 * *$ & Tolak H $_{0}$ \\
\hline
\end{tabular}

Keterangan: **: Signifikan pada taraf 5 persen

Sumber: Data primer, data diolah (2020)

Koefisien-koefisien path analysis digunakan untuk melihat pengaruh langsung pada tiap variabel laten. Pada Tabel 7, dapat dilihat hubungan variabel laten inklusi keuangan terhadap minat investasi dan literasi keuangan terhadap minat investasi. Nilai positif pada koefisien path analysis menunjukkan arah hubungan yang positif antar variabel laten dan begitu pula jika nilai koefisien path analysis bernilai negatif, maka akan menunjukkan arah hubungan yang negatif antar variabel laten. Dari Tabel 7 terlihat bahwa besarnya pengaruh variabel inklusi keuangan terhadap minat investasi adalah sebesar 3,903, yang artinya setiap kenaikan variabel inklusi keuangan sebesar satu satuan, maka akan terjadi peningkatan pada minat investasi sebesar 3,903 satuan. Variabel literasi keuangan memiliki pengaruh terhadap minat investasi sebesar 0,963, yang berarti bahwa setiap kenaikan satu satuan pada literasi keuangan akan meningkatkan minat investasi sebesar 0,963 satuan. Selain itu, dari Tabel 7 juga dapat dilihat hasil pengujian hipotesis penelitian yang hasilnya adalah sebagai berikut:

1. Pengaruh Literasi Keuangan terihadap Perilaku Investasi

Pengaruh literasi keuangan terhadap perilaku investasi memiliki nilai original sample sebesar 0,091 dan t-statistic sebesar 0,963 yang nilainya lebih kecil dari 1,96 sehingga variabel literasi keuangan tidak berpengaruh signifikan terhadap perilaku investasi. Hal ini berarti menerima $\mathrm{H}_{0}$ dan menolak $\mathrm{H}_{1}$.

Hasil penelitian ini berbeda dengan penelitian-penelitian sebelumnya yang dilakukan oleh Malik (2017) serta Dewi dan Purbawangsa (2018) yang menyatakan bahwa variabel literasi keuangan dan faktor demografi seperti pendapatan memiliki pengaruh positif siginifikan terhadap minat investasi mahasiswa baik secara parsial maupun simultan, yang artinya semakin tinggi tingkat literasi keuangan dan pendapatan, maka semakin tinggi juga minat mahasiswa untuk berinvestasi. Penelitian lain yang dilakukan oleh Aren dan Zengin (2016) juga menyatakan bahwa literasi keuangan dapat memengaruhi investor dalam memilih produk investasi. Investor yang termasuk "risk-averter" cenderung memilih investasi dalam bentuk deposit, sementara yang termasuk "risk seeker" akan memilih foreign exchange, ekuitas, dan portofolio.

Meskipun pada penelitian sebelumnya tingkat literasi keuangan memiliki pengaruh dikarenakan walaupun sebagian besar responden pada penelitian ini memiliki tingkat literasi 
keuangan yang tergolong well literate, namun terdapat alasan lain yang menyebabkan responden memilih untuk tidak berinvestasi. Berdasarkan hasil wawancara dengan responden, alasan responden belum melakukan investasi di pasar modal antara lain seperti belum bekerja dan memiliki penghasilan sendiri, penghasilan yang diperoleh saat ini masih digunakan untuk memenuhi kebutuhan pokok, dan belum mengerti tentang prosedur dan sistem untuk berinvestasi di pasar modal. Alasan tersebut juga sama seperti yang diungkapkan Pajar (2017) dan Spaseska et al. (2016) bahwa tidak sedikit dari mahasiswa yang mengurungkan niatnya untuk berinvestasi karena minimnya sisa uang saku dan rendahnya pendapatan yang diperoleh. Grohman (2018) juga menyatakan bahwa tidak terdapat hubungan antara literasi keuangan dengan partisipasi responden kepemilikan produk pasar modal. Penelitian lain yang dilakukan oleh Irjayanti (2017) kepada warga Surabaya dan Sidoarjo juga menghasilkan bahwa literasi keuangan berpengaruh negatif tidak signifikan terhadap keputusan investasi. Dalam penelitiannya disebutkan bahwa masyarakat dengan tingkat literasi tinggi belum tentu berani untuk berinvestasi pada asset yang berisiko meskipun memiliki tingkat pengembalian yang tinggi.

\section{Pengaruh Inklusi Keuangan terihadap Perilaku Investasi}

Pengaruh inklusi keuangan terhadap perilaku investasi memiliki nilai koefisien estimasi (original sample) sebesar 0,406 dan nilai t-statistic 3,903. Hal ini berarti inklusi keuangan berpengaruh positif dan signifikan terhadap variabel perilaku investasi pada taraf signifikasi 5 persen karena nilai original sample yang positif dan nilai $t$-statistic lebih besar dari 1,96. Hal ini berarti penolakan terhadap $\mathrm{H}_{0}$ dan terima $\mathrm{H}_{1}$.

Pengaruh inklusi keuangan terhadap perilaku investasi yang positif ini berarti bahwa setiap peningkatan nilai inklusi keuangan maka akan meningkatkan perilaku investasi. Semakin banyak masyarakat generasi $\mathrm{Z}$ yang memiliki akses terhadap produk-produk tabungan dan investasi, produk pembayaran, produk asuransi, serta produk-produk kredit atau pinjaman, maka semakin besar juga kecenderungan masyarakat dalam berinvestasi. Pengaruh inklusi keuangan terhadap perilaku investasi yang positif mendukung penelitian sebelumnya yang dilakukan oleh Hasundungan (2019) yang menyatakan bahwa inklusi keuangan memiliki pengaruh yang positif dan signifikan terhadap perilaku investasi. Hal ini berarti jika akses terhadap layanan keuangan meningkat, maka minat untuk memiliki produk pasar modal akan semakin tinggi. Sama halnya seperti penelitian yang dilakukan oleh Wibowo (2018), dengan hasil yaitu akses terhadap pasar modal juga merupakan salah satu faktor yang memengaruhi minat investasi.

\section{KESIMPULAN}

Merujuk pada hasil penelitian ini, dapat disimpulkan bahwa tingkat literasi keuangan generasi $\mathrm{Z}$ di Jabodetabek dapat diketahui bahwa yang termasuk ke dalam kelompok well literate adalah sebesar 61 persen dan rata-rata tingkat inklusi keuangan generasi $Z$ di Jabodetabek adalah 64 persen. Hal ini berarti bahwa sebagian besar generasi $\mathrm{Z}$ di Jabodetabek telah memiliki kemampuan dan keyakinan tentang pengetahuan keuangan, perilaku keuangan, dan sikap keuangan. Selain itu diperoleh hasil yang menunjukkan literasi keuangan tidak berpengaruh signifikan terhadap minat investasi generasi $Z$ di Jabodetabek. Hal ini berarti bahwa peningkatan literasi keuangan generasi $\mathrm{Z}$ di Jabodetabek tidak diikuti dengan peningkatan minat investasi. Sementara itu, inklusi keuangan memiliki pengaruh yang signifikan terhadap minat investasi generasi $\mathrm{Z}$ di Jabodetabek. Inklusi keuangan berpengaruh signifikan terhadap minat investasi menunjukkan bahwa jika masyarakat yang termasuk ke dalam kelompok generasi $\mathrm{Z}$ memiliki akses yang luas terhadap produk dan jasa keuangan yang akan meningkatkan minat untuk berinvestasi. 


\section{DAFTAR PUSTAKA}

[BPS] Badan Pusat Statistik. (2018). Survei Sosial Ekonomi Nasional 2017. Tersedia pada: http://microdata.bps.go.id/mikrodata/index.php

[OECD] Organization for Economic Co-operation and Development. (2016). OECD/INFE International Survey of Adult Financial Literacy Competencies. Paris: Organization for Economic Cooperation Development.

[OECD] Organization for Economic Co-operation and Development. (2018). OECD/INFE Toolkit for Measuring Financial Literacy and Financial Inclusion. Paris: OECD.

[OECD] Organization for Economic Co-operation and Development. (2017). G20/OECD INFE Report on Adult Financial Literacy in G20 Countries. Paris: OECD.

[OECD] Organization for Economic Co-operation and Development. (2013). Financial Literacy and Inclusion: Results of OECD/INFE Survey Accross Countries and by Gender. Paris: OECD.

[OJK] Otoritas Jasa Keuangan. (2017). Strategi Nasional Literasi Keuangan Indonesia (Revisit). Jakarta: OJK.

[OJK] Otoritas Jasa Keuangan. (2019). Siaran Pers Survei OJK: Indeks Literasi dan Inklusi Keuangan Meningkat. Jakarta: OJK

[OJK] Otoritas Jasa Keuangan. (2019). Survei Nasional Literasi dan Keuangan Inklusi Keuangan 2019. Jakarta: OJK.

Aminatuzzahra. (2014). Persepsi Pengaruh Pengetahuan Keuangan, Sikap Keuangan, Sosial Demografi, Terhadap Perilaku Keuangan dalam Pengambilan Keputusan Investasi Individu (Studi Kasus pada Mahasiwa Magister Manajemen Universitas Diponegoro). Jurnal Bisnis Strategi, 23(2), 70-96.

Aren, S., \& Zengin, A. N. (2016). Influence of Financial Literacy and Risk Perception on Choice of Investment. Procedia - Social and Behavioral Science, 235, 656-663.

Atkinson, A., \& Messy, F. (2012). Measuring Financial Literacy: Result of The OECD/ International Network on Financial Education (INFE) Pilot Study. Paris: Organization for Economic Cooperation Development.

Dewi, I. G. A. M., \& Purbawangsa, I. B. A. (2018). Pengaruh Literasi Keuangan, Pendapatan, Serta Masa Bekerja Terhadap Perilaku Keputusan Investasi. E-Journal Ekonomi dan Bisnis Universitas Udayana, 7(7), 1867-1894.

Dwidienawati, D., \& Gandasari, D. (2018). Understanding Indonesia's Generation Z. International Journal of Engineering and Technology, 3, 245-252.

Faidah, F. (2019). Pengaruh Literasi Keuangan dan Faktor Demografi Terhadap Minat Investasi Mahasiswa. Journal of Applied Business and Economic, 5(3), 251-263.

Filipiak, U., \& Walle, Y. M. (2015). The Financial Literacy Gender Gap; A Question of Nature or Nurture?. Georg-August-Universität Göttingen, Courant Research Centre - Poverty, Equity and Growth (CRC-PEG), Göttingen. Discussion Papers. 176.

Financial Inclusion Overview - World Bank. Tersedia pada http://www.worldbank.org/en/topic/financialinclusion/overview [diakses pada 1 Februari 2020]

Ghozali, I. (2014). Structural Equation Modeling Metode Alternatif dengan Partial Least Square $(P L S)$. Edisi 4. Semarang: BadanPenerbit Univ. Dipenegoro

Grohman, A. (2018). Financial Literacy and Financial Behavior Evidence from The Emerging Asian Middle Class. Pacific-Basin Finance Journal, 48, 129-143.

Grohmann, A., Theres, K., \&Menkhoff L. (2018). Does Financial Literacy Improve Financial Inclusion? Cross Country Evidence. Journal of World Development, 111, 84-96.

Jurnal Manajemen dan Organisasi

(JMO),

Vol. 12 No. 3,

Hal. 252-264

Hair, J., Kuppelwieser, V., \& Sarstedt, M. (2014). Partial Least Square Structural Equation Modeling (PLS-SEM): AN Emerging Tool for Business Research. European Business Review, 2.

Hasundungan, S. (2019). Literasi, Inklusi Keuangan, Penggunaan Produk Fintech, dan Perilaku Investasi pada Generasi Milenial di Jabodetabek. Bogor: IPB. 
Howe, N., \& Strauss, W. (2000). Millenials Rising: The Next Great Generation. New York: Vintage.

Irjayanti, D. (2017). Pengaruh Literasi Keuangan, Representativeness, Familiarity, dan Persepsi Risiko terhadap Pengambilan Keputusan Investasi Pada Investor Surabaya dan Sidoarjo. Surabaya: Sekolah Tinggi Ilmu Ekonomi Perbanas [Skripsi].

Jappelli, T., \& Padula, M. (2013). Investment in Financial Literacy and Saving Decisions. Journal of Banking \& Finance, 37(8), 2779-92.

Klapper, L., Lusardi, A., \& Oudheusden, P. (2015). Financial Literacy Around The World: Insight from The Standard and Poor Rating Service Global Financial Literacy Survey. Washington DC (US): GFLEC.

Morgan, P. J., \& Long, T. Q. (2020). Financial Literacy, Financial Inclusion, and Savings Behavior in Laos. Journal of Asian Economics. ABDI working paper No. 933.

OECD/INFE. (2018). Financial Inclusion and Consumer Empowerment in Southeast Asia. Paris: OECD. Available at: http://www.oecd.org/finance/Financial-inclusion-andconsumerempowerment-in-Southeast-Asia.pdf

Pajar, R. C. (2017). Pengaruh Motivasi Investasi dan Pengetahuan Investasi terhadap Minat Investasi di Pasar Modal pada Mahasiswa FE UNY. Yogyakarta: UNY

Putri, N. M. D. R., \& Rahyuda, H. (2017). Pengaruh Tingkat Financial Literacy Dan Faktor Sosiodemografi Terhadap Perilaku Keputusan Investasi Individu. E-Jurnal Ekon dan Bisnis Univ Udayana, 6(9), 3407-3434. doi:10.24843/eeb.2017.v06.i09.p09.

Spaseska, T., Risteska, A., Vitanova, G., Odzaklienska, D., \& Risteska, F. (2016). Analysis of Knowledge about Capital Market Activities in Republic of Mecedonia. Society of Economists Ekonomika, Nis, Serbia, 62(2).

TD Ameritrade. (2012). Generation Z and Money Survey: Understandinf Tomorrow's Investor. [Diunduh pada 9 Januari 2020].

Tripambudi, B., \& Indrawati, E. S. (2018). Hubungan antara kontrol diri dengan minat konsumtif pembelian gadget pada mahasiswa teknik industri universitas diponegoro. Jurnal Empati, 7(2), 189-195.

Triyaningsih, S. L. (2011). Dampak online marketing melalui facebook terhadap minat konsumtif masyarakat. Journal Ekonomi dan Wirausaha, 11(2), 172-177

Tustin, D. H. (2010). An impact asesment of a prototype financial literacy flagship programme in a rural South Africa setting. African Journal of Business Management, 4(9), 1894-1902.

Wibowo, A., \& Purhandoko. (2019). Pengaruh Pengetahuan Investasi, Kebijakan Modal Minimal Investasi, dan Pelatihan Pasar Modal Terhadap Minat Investasi (Studi Kasus Mahasiswa FE Unesa yang Terdaftar di Galeri Investasi Unesa). Jurnal Ilmu Manajemen, 7(1).

Wibowo, M. Y. (2018). Pengaruh Literasi Keuangan dan Akses Terhadap Keputusan Berinvestasi di Pasar Modal Syariah (Studi Kasus: Investor di Galeri Investasi Bursa Efek Indonesia Fakultas Ekonomi dan Bisnis Syariah IAIN Surakarta). Surakarta: IAIN Surakarta. 